\title{
Effects of fish oil and starch added to a diet containing sunflower-seed oil on dairy goat performance, milk fatty acid composition and in vivo $\Delta 9$-desaturation of $\left[{ }^{13} \mathrm{C}\right]$ vaccenic acid
}

\author{
Laurence Bernard $^{1 *}$, Julien Mouriot ${ }^{1,2}$, Jacques Rouel ${ }^{1}$, Frédéric Glasser $^{1}$, Pierre Capitan ${ }^{1}$, \\ Estelle Pujos-Guillot ${ }^{2}$, Jean-Michel Chardigny ${ }^{2,3}$ and Yves Chilliard ${ }^{1}$ \\ ${ }^{1}$ INRA, UR1213 Herbivores, Equipe Tissu Adipeux et Lipides du Lait, Site de Theix, F-63122 Saint-Genès-Champanelle, France \\ ${ }^{2}$ INRA, UMR 1019 Nutrition Humaine, F-63122 Saint-Genès-Champanelle, France \\ ${ }^{3}$ Clermont Université, UFR Médecine, UMR 1019 Nutrition Humaine, F-63000 Clermont-Ferrand, France
}

(Received 29 July 2009 - Revised 25 January 2010 - Accepted 26 January 2010 - First published online 22 March 2010)

\begin{abstract}
The potential benefits on human health have prompted an interest in developing nutritional strategies for specifically increasing rumenic acid (RA) in ruminant milk. The aims of the present study were to (i) compare two dietary treatments with lipid supplements on milk yield and composition, (ii) measure the in vivo $\Delta$ 9-desaturation of vaccenic acid (VA) to RA using ${ }^{13} \mathrm{C}$-labelled VA and (iii) determine the effect of the dietary treatments on this variable. Treatments were $90 \mathrm{~g}$ sunflower-seed oil (SO) per d or $60 \mathrm{~g}$ sunflower-seed oil and $30 \mathrm{~g}$ fish oil per d plus additional starch (SFO), in a grassland hay-based diet given to eight Alpine goats in a $2 \times 2$ cross-over design with $21 \mathrm{~d}$ experimental periods. Milk yield and composition were similar between treatments. Goats fed SFO had higher milk 6:0-16:0 concentration, lower milk $\Sigma$ C18 concentrations and showed no effect on milk VA and RA, compared with SO. At the end of the experiment, intravenous injection of $1.5 \mathrm{~g}\left[{ }^{13} \mathrm{C}\right] \mathrm{VA}$ followed by measurements of milk lipid ${ }^{13} \mathrm{C}$ enrichment showed that in vivo 31.7 and $31.6 \%$ of VA was $\triangle 9$-desaturated into milk RA in the caprine with the SO and SFO treatments, respectively. The expression of genes encoding for $\triangle 9$-desaturase (or stearoyl-CoA desaturase; SCD1, SCD5) in mammary tissues and four milk $\Delta 9$-desaturation ratios were similar between treatments. In conclusion, the present study provides the first estimates of in vivo endogenous synthesis of RA (63-73\% of milk RA) from VA in goats, and shows no difference between the two lipid supplements compared.
\end{abstract}

Sunflower-seed oil: Fish oil: Goat milk: $\Delta 9$-Desaturase: Vaccenic acid

Ruminant-derived foods (meat and milk) are the main source of conjugated linoleic acid in the human $\operatorname{diet}^{(1)}$, with evidence in animal models that the predominant isomer, cis-9, trans-11, exhibits anticarcinogenic and anti-atherogenic properties ${ }^{(2)}$. In milk, cis-9, trans-11-conjugated linoleic acid (rumenic acid; RA) is derived both from ruminal metabolism of $18: 2 n-6$ and further absorption and uptake by the mammary gland, and from endogenous $\Delta 9$-desaturation of trans-11-18:1 (vaccenic acid; VA), an intermediate of linoleic $(18: 2 n-6)$ and linolenic $(18: 3 n-3)$ acid metabolism in the rumen ${ }^{(3)}$. In addition, oleic acid is the main unsaturated fatty acid found in milk TAG and is considered to exert positive effects on human health ${ }^{(4)}$. Like RA from VA, most oleic acid is synthesised from endogenous $\Delta 9$-desaturation of $18: 0$. For these reasons, the regulation of the $\Delta 9$-desaturase system in the ruminant mammary gland may modulate the milk fat content of these fatty acids.

In bovines, the few studies that have estimated the endogenous desaturation of VA to RA employed three different methods. Two of them are indirect, involving either an inhibition of the desaturase system $^{(5)}$, or a quantification of the duodenal and milk flows of VA and RA ${ }^{(6,7)}$. Recently, Mosley et $a{ }^{\left({ }^{(8)}\right.}$ developed and used a third method using tracer methodology to measure the in vivo conversion of VA to RA in the mammary gland. This study showed that the mammary gland is the major site of $\Delta 9$-desaturation of VA in the lactating cow. However, no data are available in goats on in vivo conversion of VA to RA, although a close relationship between milk RA and VA has been established ${ }^{(9)}$.

Nutrition is the main environmental factor regulating milk fat synthesis and fatty acid composition in ruminants ${ }^{(10)}$, with caprine response differing from bovine in terms of milk fat synthesis and, to a lesser extent, milk fatty acid composition $^{(9,11)}$. A nutritional strategy to increase VA supply to the mammary gland is to feed animals with either plant oil or marine oil. In cows, feeding a lipid source rich in linoleic acid along with fish oil very effectively increased concentrations and yields of milk RA and $\mathrm{VA}^{(12)}$. Also, sunflower-seed oil in combination with fish oil was more effective than sunflower-seed oil alone in increasing milk

Abbreviations: FAME, fatty acid methyl esters; p.i., post-injection; RA, rumenic acid; SCD, stearoyl-CoA desaturase; SFO, sunflower-seed oil and fish oil plus

additional starch treatment; SO, sunflower-seed oil treatment; TTR, tracer:tracee ratio; VA, vaccenic acid.

* Corresponding author: Dr Laurence Bernard, fax +33 473 624519, email laurence.bernard@clermont.inra.fr 
concentrations of VA and $\mathrm{RA}^{(13)}$. Similar results were observed in goats, comparing fish oil in combination with sunflower-seed oil with fish oil alone ${ }^{(14)}$. These effects are a consequence of higher ruminal VA intermediate production due to the inhibition by very-long-chain fatty acids from fish oil of the final biohydrogenation step of dietary PUFA to $18: 0$. In addition, in cows, interaction between either plant or marine oils and high levels of starch in the diet increased the trans-10-18:1 pathway $^{(15)}$ and induced milk fat depression. However, in goats such diets increased milk trans-10-18: 1 without inducing milk fat depression ${ }^{(11,16)}$.

To address these issues, the first aim of the present study was to compare two dietary treatments in a $2 \times 2$ cross-over design with addition of sunflower-seed oil ( $\mathrm{SO}$ ) alone or in combination with fish oil plus additional starch (SFO) on milk yield and composition. The second aim was to investigate the metabolism of VA in the lactating goat by measuring the conversion of VA to RA using a chemical tracer strategy allowing an in vivo measurement of the $\Delta 9$-desaturation of VA. This measurement is based on the hypothesis that in goats the mammary gland is the major site of conversion of VA to RA as demonstrated in cows, even though we cannot exclude the possibility of a limited conversion in other tissues. The data of VA conversion to RA can be related to the expression of genes encoding for $\Delta 9$-desaturase (or stearoyl-CoA desaturase; SCD), SCD1 and the recently described SCD5 ${ }^{(17)}$, and to the milk fatty acid normalised $\Delta 9$-desaturation ratios, thus allowing an evaluation of the indirect variables used to estimate the mammary $\Delta 9$-desaturation. The third aim was to evaluate the effect of the two dietary treatments (SO and SFO) on the $\Delta 9$-desaturation of $\mathrm{VA}$ in vivo and on the fraction of milk RA originating from VA. The second and third aims were only achieved during the last experimental period. We hypothesised that milk RA and VA in goats fed sunflower-seed oil combined with fish oil would be higher than with sunflower-seed oil alone and that the interaction of oils with starch in the diet would increase the ruminal trans-10-18: 1 pathway, which would consequently lead to a simultaneous increase in trans-11- and trans-10-18:1. The subsequent hypothesis was that $\mathrm{SO}$ in combination with fish oil plus additional starch would negatively affect the mammary $\Delta 9$-desaturase activity through an increase in the availability of either trans-10 fatty acids or long-chain PUFA of fish oil, which have both been associated in cows with a decrease in $\Delta 9$-desaturase activity ${ }^{(3,18)}$

\section{Materials and methods}

\section{Animals, management and experimental design}

All experimental procedures were approved by the Animal Care Committee of INRA in accordance with the Use of Vertebrates for Scientific Purposes Act of 1985. Goats were housed in individual stalls, had free access to water and were milked at 07.30 and 15.30 hours.

To measure the incorporation and $\Delta 9$-desaturation of ${ }^{13} \mathrm{C}$-labelled VA in milk lipids, we first determined in a preliminary study the effect of the form and dose of injection of $\left[1-{ }^{13} \mathrm{C}\right] \mathrm{VA}$ on the kinetics of milk $\left[{ }^{13} \mathrm{C}\right] \mathrm{VA}$ enrichment.

In this preliminary experiment, two multiparous nonpregnant Alpine goats (322 (SD 7) d in milk) received a diet of lucerne hay distributed ad libitum and a mixture of concentrate (composed of $65 \%$ maize, $15 \%$ soyabean meal and $20 \%$ dehydrated sugarbeet pulp). The goats were fed twice per $\mathrm{d}$ just after milking and the amounts fed and refused were recorded daily. The goats were randomly assigned to a treatment of $\left[1-{ }^{13} \mathrm{C}\right] \mathrm{VA}$ as either NEFA or TAG (containing $51 \%\left[1-{ }^{13} \mathrm{C}\right] \mathrm{VA}$ and $49 \%$ oleic acid) (CEA, Cadarache, France). Two doses of 0.25 and $0.50 \mathrm{~g}\left[1-{ }^{13} \mathrm{C}\right] \mathrm{VA}$ of each form (NEFA or TAG) were delivered to the same goat at 1 -week intervals by jugular infusion. Doses were prepared using a modified procedure of Viswanadha et al. ${ }^{(19)}$. Briefly, $\left[1-{ }^{13} \mathrm{C}\right]$ VA as NEFA (pure at $99 \%$ ) or TAG was suspended in $25 \mathrm{ml}$ of $20 \%$ Intralipid (Sigma-Aldrich, St Louis, MO, USA) and brought to $30 \mathrm{ml}$ with $0.9 \%(\mathrm{v} / \mathrm{v})$ saline solution. Three sonication cycles of $30 \mathrm{~s}$ spaced by $30 \mathrm{~s}$ in ice were run to ensure thorough mixing. The dose was delivered at 07.30 hours by jugular injection. The goats were completely milked $24 \mathrm{~h}$ and $16 \mathrm{~h}$ before and immediately before the injection, every $4 \mathrm{~h}$ for $24 \mathrm{~h}$ post-injection (p.i.) and then every $12 \mathrm{~h}$ until $72 \mathrm{~h}$ p.i. This preliminary study was designed to determine the appropriate delivery form of $\left[1-{ }^{13} \mathrm{C}\right] \mathrm{VA}$ as either TAG or NEFA, and the best $\left[1-{ }^{13} \mathrm{C}\right] \mathrm{VA}$ assay and sampling times for the subsequent nutritional study.

In the nutritional study, eight multiparous non-pregnant Alpine goats (266 (SD 7) d in lactation) were fed two diets in a $2 \times 2$ cross-over design with four animals per group. Each experimental period $(21 \mathrm{~d})$ comprised of a $14 \mathrm{~d}$ adaptation period followed by a $7 \mathrm{~d}$ sampling period. Goats were fed in two equal meals at 08.30 and 16.30 hours, just after milking. The amounts fed and refused were recorded daily. The two experimental diets consisted of a natural grassland hay-based diet distributed ad libitum and a concentrate mixture (determined according to the initial milk yield). The diet (Table 1) included a lipid supplement of $90 \mathrm{~g}$ sunflowerseed oil alone per d (SO; Huileries de Lapalisse SA, Lapalisse, F-03 120 France) or a combination of $60 \mathrm{~g}$ sunflower-seed oil and $30 \mathrm{~g}$ fish oil from anchovy per d (SA Daudruy Van Cauwenberghe \& Fils, Dunkerque, F-59640 France) plus additional starch from rolled barley (SFO; Table 1).

\section{Measurements and sampling}

During each sampling period, representative samples of hay and concentrates were composited daily and stored at $-20^{\circ} \mathrm{C}$. We measured the chemical composition of feedstuff ingredients using standard procedures ${ }^{(20)}$. Milk yields of individual goats were recorded three times a week. Samples of milk for the measurement of fat, protein and lactose were collected from each goat over four consecutive milkings starting at 08.00 hours on day 19 of each experimental period and treated with preservative (potassium bichromate; Merck, Fontenay-sous-Bois, France). Milk fat, protein and lactose were assayed by near-IR spectroscopy (CILAL, Theix, France $\left.{ }^{(20)}\right)$. Two samples of milk were collected (morning and afternoon milkings) on day 20 of each experimental period, and stored at $-20^{\circ} \mathrm{C}$ until determination of fatty acid composition on a combined sample.

On day 18 of the last experimental period (P2), a single dose of $1.5 \mathrm{~g}\left[1-{ }^{13} \mathrm{C}\right] \mathrm{VA}$ as NEFA (CEA, Cadarache, France), as previously described, was delivered to the goats by jugular injection at 07.30 hours just after milking. 
Table 1. Ingredients and chemical composition of the ingested experimental diets

(Mean values and pooled standard errors for eight samples per treatment)

\begin{tabular}{|c|c|c|c|c|}
\hline \multirow[b]{2}{*}{ Item } & \multicolumn{2}{|c|}{ Treatment } & \multirow[b]{2}{*}{ SEM } & \multirow[b]{2}{*}{$P$} \\
\hline & so & SFO & & \\
\hline \multicolumn{5}{|l|}{ Ingredients (g/kg DM) } \\
\hline Natural grassland hay & 662 & 681 & 11.78 & 0.31 \\
\hline Rolled barley & 132 & 218 & 5.52 & $<0.01$ \\
\hline Dehydrated sugarbeet pulp & 90 & 0 & $4 \cdot 20$ & $<0.01$ \\
\hline Soyabean meal & 60 & 44 & 1.89 & $<0.01$ \\
\hline Sunflower-seed oil ${ }^{\star}$ & 46 & 30 & 1.77 & $<0.01$ \\
\hline Fish oil† & 0 & 15 & 0.41 & $<0.01$ \\
\hline Mineral-vitamin mix $\ddagger$ & 10 & 11 & $0 \cdot 17$ & 0.16 \\
\hline \multicolumn{5}{|l|}{ Chemical composition (g/kg DM) } \\
\hline Organic matter & 918 & 921 & 0.72 & 0.10 \\
\hline Crude protein & 156 & 153 & 0.39 & $<0.01$ \\
\hline Neutral-detergent fibre & 461 & 449 & $4 \cdot 16$ & 0.10 \\
\hline Acid-detergent fibre & 236 & 226 & $2 \cdot 53$ & 0.04 \\
\hline Starch & 75 & 124 & 3.06 & $<0.01$ \\
\hline Diethyl ether extract & 62 & 62 & 1.69 & 1.00 \\
\hline $14: 0$ & 0.14 & 1.28 & 0.031 & $<0.01$ \\
\hline $16: 0$ & $6 \cdot 60$ & 7.95 & 0.098 & $<0.01$ \\
\hline cis-9-16: 1 & $0 \cdot 10$ & 1.38 & 0.035 & $<0.01$ \\
\hline $18: 0$ & 0.31 & 0.74 & 0.012 & $<0.01$ \\
\hline cis-9-18: 1 & 13.46 & 11.25 & 0.498 & 0.03 \\
\hline cis-11-18: 1 & 0.09 & 0.55 & 0.013 & $<0.01$ \\
\hline $18: 2 n-6$ & 29.56 & $21 \cdot 17$ & 1.039 & $<0.01$ \\
\hline $18: 3 n-3$ & $6 \cdot 18$ & $6 \cdot 32$ & 0.066 & 0.19 \\
\hline $20: 5 n-3$ & 0.08 & 1.38 & 0.036 & $<0.01$ \\
\hline $22: 6 n-3$ & 0.01 & 1.01 & 0.027 & $<0.01$ \\
\hline Other fatty acids & $3 \cdot 32$ & $6 \cdot 00$ & 0.074 & $<0.01$ \\
\hline$\Sigma$ Fatty acids & 59.9 & 59.5 & 1.537 & 0.87 \\
\hline
\end{tabular}

SO, sunflower-seed oil; SFO, sunflower-seed oil and fish oil (2:1) plus starch from rolled barley.

* Sunflower-seed oil contained (g/kg): 14:0, 0.9; 16:0, 72.0; cis-9-16:1, 1.3 cis-9-18:1, 290.8; 18:2n-6, 597.1; 18:3n-3, 14.9; $20: 5 n-3,1.8 ; 22: 6 n-3,0.2$

†Fish oil contained $(\mathrm{g} / \mathrm{kg}): 14: 0,79.0 ; 16: 0,169 \cdot 5 ;$ cis-9-16:1, 89.3; 18:0, 29.8; cis-9-18:1, 147.9; 18:2n-6, 39.5; 18:3n-3, 16.0; 20:5n-3, 91.6; 22:6n-3, 69.0.

$\ddagger$ Mineral-vitamin supplement declared as containing $(\mathrm{g} / \mathrm{kg})$ : Ca, 240; P, 60; Mg, 50; Na, 15; Zn, 7; Mn, 6; $\alpha$-tocopherol, 0.3; retinol, 0.2; cholecalciferol, 0.002 (Usine d'Ussel, Murat, France).

The goats were completely milked every $6 \mathrm{~h}$ for $24 \mathrm{~h}$ before the injection, every $4 \mathrm{~h}$ for $24 \mathrm{~h}$ and then every $12 \mathrm{~h}$ for $72 \mathrm{~h}$ p.i. During this sequence of milk collection, milk yield was recorded, and milk samples were collected for analysis of milk fat content for each milking (CILAL, Theix, France ${ }^{(20)}$ ). Samples of $3 \mathrm{ml}$ milk were taken and stored at $-20^{\circ} \mathrm{C}$ for fatty acid composition and ${ }^{13} \mathrm{C}$ enrichment measurements.

At the end of the experiment on day 21 of P2, the goats were slaughtered after the morning milking. Immediately before slaughtering, the goats were milked to remove milk from the mammary glands. Immediately after death, samples of mammary tissue were collected under sterile conditions, frozen in liquid $\mathrm{N}_{2}$ and maintained at $-80^{\circ} \mathrm{C}$ until RNA extraction.

\section{Lipid analysis}

Lipids in natural grassland hay and concentrates were extracted and transesterified as described previously ${ }^{(16)}$. Lipids in $100 \mathrm{mg}$ of lyophilised milk samples from both experiments were directly methylated by in situ transesterification with $1 \mathrm{ml} 0.5 \mathrm{M}$-methanolic $\mathrm{NaOCH}_{3}$ at room temperature for $20 \mathrm{~min}$, followed by the addition of $1 \mathrm{ml} 14 \%(\mathrm{v} / \mathrm{v})$ boron trifluoride in methanol also at room temperature for $20 \min ^{(21)}$. Fatty acid methyl esters (FAME) were quantified as described previously ${ }^{(16)}$.

For the measurement of $\left[{ }^{13} \mathrm{C}\right] \mathrm{VA}$ enrichment, the FAME were converted to dimethyl disulfide adducts using an adaptation of the method used by Mosley et al. ${ }^{(22)}$. In brief, the FAME fractions $(<1 \mathrm{mg})$ were treated with $0.35 \mathrm{ml}$ dimethyl disulfide and $100 \mu \mathrm{l}$ iodine solution (6\% iodine $(w / v)$ in diethyl ether). The reaction mixtures were shaken in a $37^{\circ} \mathrm{C}$ water-bath for $1 \mathrm{~h}$ and diluted with diethyl ether-hexane $(3 \mathrm{ml}, 1: 1, \mathrm{v} / \mathrm{v})$. Iodine was removed by shaking with $10 \%$ sodium thiosulfate $(200 \mu \mathrm{l})$. The organic phase was removed and evaporated under $\mathrm{N}_{2}$ gas. The residue was dissolved in $1500 \mu \mathrm{l}$ hexane and analysed by GC-MS (Agilent model 7890A GC system attached to an Agilent model 5975C inert XL EI/CI mass detector; Agilent Technologies France, Massy, France). A $30 \mathrm{~m} \times 0.25 \mathrm{~mm}$ internal diameter, $0.25 \mu \mathrm{m}$ film thickness capillary column, crosslinked 5\% diphenyl $95 \%$ dimethyl siloxane (HP5MS) from Agilent Technologies was used for chromatographic separation. The injection volume was $1 \mu \mathrm{l}$ in splitless mode at $250^{\circ} \mathrm{C}$, with $\mathrm{He}$ as the carrier gas at a constant flow rate of $1 \mathrm{ml} / \mathrm{min}$. The oven temperature program was started at $70^{\circ} \mathrm{C}$, increased at a rate of $20^{\circ} \mathrm{C} / \mathrm{min}$ to $195^{\circ} \mathrm{C}$, then at a rate of $1^{\circ} \mathrm{C} / \mathrm{min}$ to $225^{\circ} \mathrm{C}$ (held for $5 \mathrm{~min}$ ), and finally at a rate of $10^{\circ} \mathrm{C} / \mathrm{min}$ to $290^{\circ} \mathrm{C}$ (held for $5 \mathrm{~min}$ ). The transfer line heater was set at $300^{\circ} \mathrm{C}$. The mass spectrometer was operated under electron impact ionisation conditions (electron energy $70 \mathrm{eV}$, source temperature $200^{\circ} \mathrm{C}$ ). The fragment ions $\mathrm{m} / \mathrm{z}$ 245 and 246 for dimethyl disulfide derivatives were monitored using selective ion monitoring.

The enrichment of $\left[{ }^{13} \mathrm{C}\right] \mathrm{RA}$ was measured directly from FAME $^{(23)}$ by GC-MS (Agilent model 7890A GC system attached to an Agilent model 5975C inert XL EI/CI mass detector; Agilent Technologies France) on a $100 \mathrm{~m} \times$ $0.25 \mathrm{~mm}$ internal diameter fused silica capillary column (CP-Sil 88; Chrompack 7489, Middelburg, The Netherlands). Injection volume was $1 \mu \mathrm{l}$ in splitless mode at $250^{\circ} \mathrm{C}$, with $\mathrm{He}$ as the carrier gas, at a constant pressure of 30 pounds per square inch $(206.84 \mathrm{kPa})$. The oven temperature program was started at $60^{\circ} \mathrm{C}$, increased at a rate of $15^{\circ} \mathrm{C} / \mathrm{min}$ to $165^{\circ} \mathrm{C}$ (held for $1 \mathrm{~min}$ ), then at a rate of $2^{\circ} \mathrm{C} / \mathrm{min}$ to $225^{\circ} \mathrm{C}$ (held for $5 \mathrm{~min}$ ). The mass spectrometer was operated under positive chemical ionisation with ammonia reagent gas at $20 \mathrm{ml} / \mathrm{min}$. Data were obtained in scan mode with a mass range of $m / z 60-400$.

\section{$R N A$ isolation and real-time RT-PCR}

Total RNA was prepared from about $85 \mathrm{mg}$ mammary tissues using TRIZOL Reagent (Invitrogen Life Technologies, Carlsbad, CA, USA) and further purified with the SV Total RNA Isolation system (Promega, Charbonnières, France) to eliminate contaminating genomic DNA before cDNA synthesis. RNA concentration and purity were determined by spectrophotometry at 260, 280 and $320 \mathrm{~nm}$ (Lambda 25 UV/VIS spectrometer; Perkin Elmer Instruments, Les Ulis, France) and RNA integrity was verified using a Bioanalyser 2100 (Agilent Technologies, Massy, France). Quantitative RT-PCR was carried out as described previously ${ }^{(24)}$. 
Specific primers were previously described for $S C D 1^{(24)}$ and $S C D 5^{(17)}$. Abundance of SCD1 and SCD5 gene transcripts was expressed as fold change relative to SO treatment after normalisation with cyclophilin A (reference gene) to account for variations in RNA integrity, RNA quantification and cDNA synthesis.

\section{Calculations}

The tracer:tracee ratio (TTR) was calculated for VA and RA from the mass abundance of the ${ }^{13} \mathrm{C}$ and ${ }^{12} \mathrm{C}$ fragments using the equation TTR $={ }^{13} \mathrm{C} /{ }^{12} \mathrm{C}$.

For VA, TTR was calculated from GC-MS single ion monitoring data on specific mass fragments at $\mathrm{m} / \mathrm{z} 245$ and 246 for $\mathrm{M}$ and $\mathrm{M}+1$, respectively ${ }^{(25)}$, and using a standard curve of $\left[{ }^{13} \mathrm{C}\right]$ trans-11-18:1. For RA, TTR was calculated from GC-MS scan data on specific mass fragments at $\mathrm{m} / \mathrm{z} 312$ and 313 for $\mathbf{M}$ and $\mathbf{M}+1$, respectively ${ }^{(23)}$. To account for the baseline natural isotopic abundance, the mean TTR of samples taken before the bolus was subtracted from the TTR of all samples. The enrichment $(E)$ of the fatty acid with ${ }^{13} \mathrm{C}$ for RA in milk was then (TTR - TTR mean before injection) $\times 100$. The calculated $E$ was adjusted for spectrum skewness using the correction factor $1 /(1+(0 \cdot 011))^{(26)}$.

To calculate the amounts of $\left[{ }^{13} \mathrm{C}\right] \mathrm{VA}$ and $\left[{ }^{13} \mathrm{C}\right] \mathrm{RA}$ resulting from the injected dose (hereafter called post-predicted values), first total amounts of milk VA and RA secreted at each milking for $24 \mathrm{~h}$ p.i. were calculated, and respectively separated into $\mathrm{g}\left[{ }^{13} \mathrm{C}\right] \mathrm{VA}$ and $\left[{ }^{12} \mathrm{C}\right] \mathrm{VA}$, and $\left[{ }^{13} \mathrm{C}\right] \mathrm{RA}$ and $\left[{ }^{12} \mathrm{C}\right] \mathrm{RA}$ and then summed for $24 \mathrm{~h}$ p.i. The predicted p.i. basal secretion of $\left[{ }^{13} \mathrm{C}\right] \mathrm{VA}$ or $\left[{ }^{13} \mathrm{C}\right] \mathrm{RA}$ was calculated as the mean $\%$ $\left[{ }^{13} \mathrm{C}\right] \mathrm{VA}$ or $\%\left[{ }^{13} \mathrm{C}\right] \mathrm{RA}$ value of the $24 \mathrm{~h}$ samples before injection multiplied by the $24 \mathrm{~h}$ p.i. secretion (g) of VA or RA. These values were therefore subtracted from the ${ }^{13} \mathrm{C}$ p.i. secretion of VA or RA to determine the predicted values. They were then used to calculate the amount of VA converted to RA, and the fraction of RA originating from VA, assuming that the mammary gland is the major site of $\Delta 9$-desaturation of circulating VA to milk RA. We used the following equations:

Percentage of VA converted to milk RA in vivo

$=\mathrm{g}\left[{ }^{13} \mathrm{C}\right] \mathrm{RA}$ post-predicted $/\left(\mathrm{g}\left[{ }^{13} \mathrm{C}\right] \mathrm{VA}\right.$ post-predicted

$+\mathrm{g}\left[{ }^{13} \mathrm{C}\right] \mathrm{RA}$ post-predicted).

VA secreted in milk $24 \mathrm{~h}$ p.i. (g)

$$
=\mathrm{g}\left[{ }^{13} \mathrm{C}\right] \text { VA secreted p.i. }+\mathrm{g}\left[{ }^{12} \mathrm{C}\right] \text { VA secreted p.i. }
$$

Mammary uptake of VA 24 h p.i. (g)

$$
=(\mathrm{g} \text { secreted VA p.i. } \times 100) /(100
$$

- \% VA converted to milk RA in vivo).

VA converted to milk RA $24 \mathrm{~h}$ p.i. (g)

= g mammary uptake of VA p.i.

$\times \%$ VA converted to milk RA in vivo.
Secreted RA in milk 24 h p.i. (g)

$$
=\mathrm{g}\left[{ }^{13} \mathrm{C}\right] \mathrm{RA} \text { secreted p.i. }+\mathrm{g}\left[{ }^{12} \mathrm{C}\right] \mathrm{RA} \text { secreted } \mathrm{p} . \mathrm{i} \text {. }
$$

Percentage of milk RA from VA p.i.

$$
=\text { g VA converted to RA p.i./g secreted RA p.i. }
$$

\section{Statistical analysis}

Data on DM intake, milk production and milk composition were subjected to ANOVA using the general linear models procedure of SAS (SAS Institute, Cary, NC, USA) for a $2 \times 2$ cross-over design with a model that included the effects of treatment, period and goat. Treatment means were compared using the least square means procedure (SAS Institute) with differences declared significant at $P<0 \cdot 05$. Data on in vivo $\left[{ }^{13} \mathrm{C}\right] \mathrm{VA}$ metabolism, including the amount of $\mathrm{VA}$ converted to RA and the fraction of RA originating from VA, together with the mRNA abundance in mammary tissues collected after slaughter, were statistically evaluated using the non-parametric Wilcoxon $U$ test. Treatment effects were considered significant at $P<0 \cdot 05$.

\section{Results}

\section{Diet composition}

The natural grassland hay was of high nutritional quality and had the following composition $(\mathrm{g} / \mathrm{kg}$ DM, unless otherwise stated): DM, $861 \mathrm{~g} / \mathrm{kg}$ fresh weight; organic matter, 899; crude protein, 153; acid-detergent fibre, 307; neutral-detergent fibre, 579; fatty acids, 20.

The two diets had similar organic matter and neutraldetergent fibre contents, which averaged 920 and $455 \mathrm{~g} / \mathrm{kg}$ $\mathrm{DM}$, respectively. Crude protein and acid-detergent fibre contents were slightly higher for SO than for SFO, while starch content was higher for SFO $(124 \mathrm{~g} / \mathrm{kg}$ DM) than for SO (75 g/kg DM; Table 1).

The mean forage:concentrate ratios of the diets (on a DM basis) were 68:32 and 69:31 for SO and SFO, respectively.

The major fatty acids provided by the diets were $18: 2 n-6$ and cis-9-18:1, with 56.8 and $39.0 \mathrm{~g} 18: 2 n-6$ per $\mathrm{d}$, and 25.8 and $20.7 \mathrm{~g}$ cis-9-18:1 per d, respectively for SO and SFO. In addition, SFO provided $2.5 \mathrm{~g} 20: 5 n-3$ and $1.9 \mathrm{~g}$ $22: 6 n-3$ per $d$

\section{Dairy performance and milk fatty acid composition}

The DM intake, milk yield, milk fat, protein and lactose yields were not significantly different for SO and SFO treatments (Table 2), even though a tendency to decrease for SFO treatment $(P=0.07$ to 0.08$)$ was observed. Energy and protein balances calculated as described by Jarrige ${ }^{(27)}$ were positive and similar among dietary treatments (Table 2).

Compared with SO, SFO induced higher percentages of milk short- and medium-chain SFA (6:0 to 16:0), cis-9-16:1, trans-11, cis-15-18:2, 20:5n-3 and $22: 6 n-3$ (Table 3). Conversely, SFO induced lower percentages of milk 18:0, cis-9-18:1, $\Sigma$ cis-18:1 and $\Sigma$ C18 (Table 3). 
Table 2. Effect of dietary sunflower-seed oil alone or in combination with fish oil plus starch on DM intake, milk yield and milk composition and energy and protein balances in goats

(Mean values and pooled standard errors for eight goats per treatment)

\begin{tabular}{|c|c|c|c|c|}
\hline \multirow[b]{2}{*}{ Item } & \multicolumn{2}{|c|}{ Treatment } & \multirow[b]{2}{*}{ SEM } & \multirow[b]{2}{*}{$P$} \\
\hline & so & SFO & & \\
\hline DM intake $(\mathrm{kg} / \mathrm{d})$ & 1.98 & 1.86 & 0.04 & 0.08 \\
\hline \multicolumn{5}{|l|}{ Yield $(g / d)$} \\
\hline Milk & 1930 & 1790 & 46 & 0.08 \\
\hline Fat & 93 & 81 & 3.55 & 0.07 \\
\hline Protein & 76 & 71 & 1.74 & 0.08 \\
\hline Lactose & 94 & 87 & 2.01 & 0.07 \\
\hline \multicolumn{5}{|l|}{ Concentration $(\mathrm{g} / \mathrm{kg})$} \\
\hline Fat & $47 \cdot 9$ & $46 \cdot 4$ & 1.97 & 0.64 \\
\hline Protein & $40 \cdot 0$ & 40.5 & 0.42 & 0.40 \\
\hline Lactose & 48.5 & $48 \cdot 6$ & 0.38 & 0.91 \\
\hline Energy balance $(\mathrm{kJ} / \mathrm{d})^{*}$ & 997 & 1068 & 182 & 0.92 \\
\hline Protein balance $(\mathrm{g} / \mathrm{d}) \dagger$ & 45 & 40 & 2.93 & 0.27 \\
\hline
\end{tabular}

SO, sunflower-seed oil; SFO, sunflower-seed oil and fish oil (2:1) plus starch from rolled barley.

${ }^{*}$ Calculated according to Jarrige ${ }^{(27)}$

†Protein digestible in the intestine ${ }^{(27)}$

\section{9-Desaturation}

During the preliminary experiment (Fig. 1), the $\left[{ }^{13} \mathrm{C}\right] \mathrm{VA}$ enrichments of milk fat from injection of labelled TAG and NEFA peaked respectively at 5 and $7 \mathrm{~h}$ and then declined over $60 \mathrm{~h}$ irrespective of the dose. Whatever the injected dose of $\left[{ }^{13} \mathrm{C}\right] \mathrm{VA}$, the maximal enrichment values were higher for the NEFA than for the TAG, with 7.3 and $10.6 \%$ enrichment of $\left[{ }^{13} \mathrm{C}\right] \mathrm{VA}$, respectively, for doses 1 and 2 with NEFA compared with 1.3 and $2.3 \%$ with TAG. After the first $24 \mathrm{~h}$ of milk collection, lower enrichments (close to basal values) were observed. Therefore, in the nutritional experiment, calculations were limited to the first $24 \mathrm{~h}$ to allow an accurate estimation of the $\Delta 9$-desaturation of VA.

In the nutritional experiment, the $\left[{ }^{13} \mathrm{C}\right] \mathrm{VA}$ enrichment of milk fat from the injection as NEFA peaked at 10 and $14 \mathrm{~h}$ p.i. for the SO and SFO treatments, respectively (Fig. 2), and then declined until $66 \mathrm{~h}$ p.i. Milk fat enrichments of the $\Delta$ 9-desaturase product, $\left[{ }^{13} \mathrm{C}\right] \mathrm{RA}$, followed a pattern similar to that of the substrate, $\left[{ }^{13} \mathrm{C}\right] \mathrm{VA}$, peaking at 6 and $10 \mathrm{~h}$ p.i. for the SO and SFO treatments, respectively (Fig. 2). The percentage of mammary VA uptake desaturated to milk RA was 31.7 and $31.6 \%$, respectively, for the SO and SFO treatments (Table 4). From these percentages of VA desaturated to milk RA, we calculated that 73.1 and $62.9 \%$ of milk RA came from VA desaturation for the SO and SFO treatments, respectively (Table 4). Neither the percentage of VA desaturated into milk RA nor the percentage of milk RA coming from VA desaturation was significantly different $(P>0.05)$ between treatments.

Regarding the other parameters of the $\Delta 9$-desaturation, neither the milk $\triangle 9$-desaturation ratios nor the abundance of mRNA encoding for SCD1 or SCD5 in mammary tissues (Table 5) were significantly modified by the treatments.

\section{Discussion}

The present study investigated the effects of sunflowerseed oil in combination with fish oil plus starch addition compared with sunflower-seed oil alone on milk fat yield and composition in goats. Additionally, the $\Delta 9$-desaturation of VA to RA in vivo was measured using a chemical tracer strategy and was related to other variables of mammary $\triangle 9$-desaturation such as SCD1 and SCD5 gene expression and milk normalised $\Delta 9$-desaturation ratios. The effect of the dietary treatments on these variables was explored to gain further insight into the nutritional regulation of the $\Delta 9$-desaturation in goats.

\section{Dairy performance and milk fatty acid composition}

There were no significant differences in milk production or composition between the two dietary treatments ( $\mathrm{SO}$ and SFO). In a previous study on grazing goats, Gagliostro et al. ${ }^{(14)}$ observed no differences between goats fed iso-starchy diets with either $30 \mathrm{ml}$ fish oil per $\mathrm{d}$ or $30 \mathrm{ml}$ fish oil plus $150 \mathrm{ml}$ sunflower-seed oil per $\mathrm{d}$ on milk fat, protein and lactose concentrations. Elsewhere, numerous studies have been performed in dairy cows fed fish oil demonstrating a strong negative effect on milk fat yield and percentage ${ }^{(28)}$. Altogether, these data outline that the responses of milk yield and composition to different types of lipid supplements differ greatly between goats and cows, with an absence of decrease in milk fat content and yield in goats, conversely to $\operatorname{cows}^{(9,11)}$. It is likely that these differences in dairy

Table 3. Effect of dietary sunflower-seed oil alone or in combination with fish oil plus starch on milk fatty acids composition $(\mathrm{g} / 100 \mathrm{~g}$ fatty acids) in goats

(Mean values and pooled standard errors for eight goats per treatment)

\begin{tabular}{|c|c|c|c|c|}
\hline & \multicolumn{2}{|c|}{ Treatment } & \multirow[b]{2}{*}{ SEM } & \multirow[b]{2}{*}{$P$} \\
\hline & so & SFO & & \\
\hline \multicolumn{5}{|l|}{ Fatty acid (\%) } \\
\hline $4: 0$ & 1.67 & 1.63 & 0.046 & 0.53 \\
\hline $6: 0$ & 1.75 & 1.92 & 0.039 & 0.03 \\
\hline $8: 0$ & $2 \cdot 01$ & $2 \cdot 38$ & 0.045 & $<0.01$ \\
\hline $10: 0$ & $7 \cdot 15$ & $8 \cdot 60$ & 0.117 & $<0.01$ \\
\hline $12: 0$ & $4 \cdot 17$ & $5 \cdot 27$ & 0.178 & $<0.01$ \\
\hline $14: 0$ & 8.85 & $10 \cdot 61$ & 0.255 & $<0.01$ \\
\hline cis-9-14:1 & 0.21 & 0.26 & 0.021 & 0.14 \\
\hline $16: 0$ & $18 \cdot 18$ & 21.34 & 0.442 & $<0.01$ \\
\hline cis-9-16:1 & 0.62 & 0.92 & 0.023 & $<0.01$ \\
\hline $18: 0$ & 9.85 & 4.90 & 0.632 & $<0.01$ \\
\hline cis-9-18:1 & $21 \cdot 71$ & 13.90 & 0.829 & $<0.01$ \\
\hline$\sum$ cis- $18: 1$ & 23.57 & $15 \cdot 41$ & 0.767 & $<0.01$ \\
\hline trans-10-18: 1 & 0.90 & 0.73 & 0.074 & $0 \cdot 18$ \\
\hline trans-11-18: 1 (VA) & 4.74 & 6.35 & 0.792 & 0.20 \\
\hline trans-12-18: 1 & 0.69 & 0.88 & 0.083 & 0.17 \\
\hline trans-13-18: 1 & 0.78 & 0.97 & 0.093 & 0.19 \\
\hline$\sum$ trans-18: 1 & $8 \cdot 10$ & 10.09 & 1.109 & 0.26 \\
\hline $18: 2 n-6$ & $3 \cdot 18$ & $2 \cdot 33$ & 0.310 & $0 \cdot 10$ \\
\hline trans -11, cis-15-18:2 & 0.02 & 0.20 & 0.035 & 0.02 \\
\hline $18: 3 n-3$ & 0.55 & 0.64 & 0.046 & 0.25 \\
\hline cis-9, trans-11-18:2 (RA) & $3 \cdot 12$ & 4.08 & 0.438 & 0.18 \\
\hline trans-10, cis-12-18:2 & $\operatorname{tr}$ & $\operatorname{tr}$ & & \\
\hline$\Sigma \mathrm{CLA}^{*}$ & $3 \cdot 24$ & 4.21 & 0.443 & 0.18 \\
\hline$\Sigma C 18$ & $49 \cdot 27$ & 38.85 & 0.724 & $<0.01$ \\
\hline $20: 5 n-3$ & 0.06 & 0.13 & 0.011 & $<0.01$ \\
\hline $22: 6 n-3$ & 0.03 & 0.09 & 0.013 & 0.03 \\
\hline
\end{tabular}

SO, sunflower-seed oil; SFO, sunflower-seed oil and fish oil (2:1) plus starch from rolled barley; VA, vaccenic acid; RA, rumenic acid; tr, concentrations below $0.01 \mathrm{~g} / 100 \mathrm{~g}$ fatty acids; CLA, conjugated linoleic acid.

* Included cis-9, trans-11-, cis-9, cis-11- and trans, trans-CLA. 


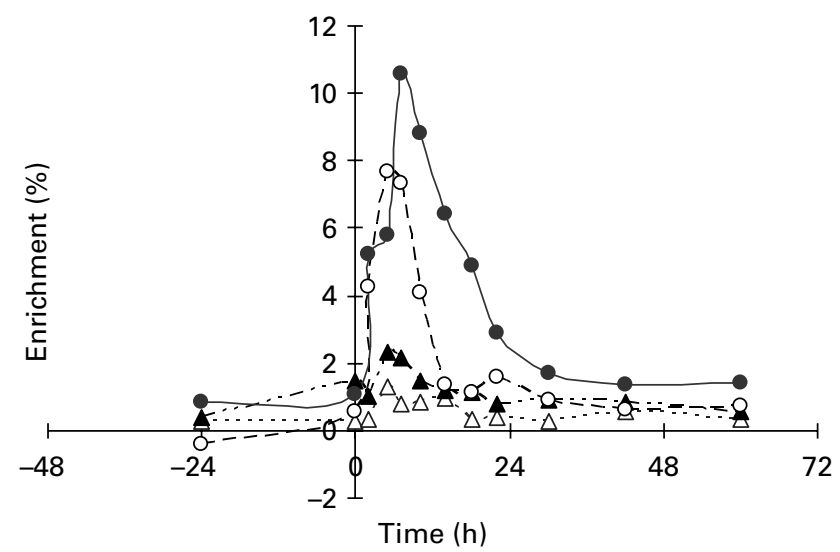

Fig. 1. Enrichment of ${ }^{13} \mathrm{C}$ in trans-11-18: 1 (vaccenic acid; VA) in milk fat of lactating goats injected intravenously with $\left[1-{ }^{13} \mathrm{C}\right] \mathrm{VA}$ at time zero, provided as NEFA or TAG, and at two doses $(0.25$ and $0.50 \mathrm{~g})$. The post-injection data are plotted at the mean time point for each collection period. Each point represents one goat. $(-\Delta-)$, TAG $0.25 \mathrm{~g} ;(-\boldsymbol{\Delta}-)$, TAG $0.50 \mathrm{~g} ;(-\mathrm{O}-)$, NEFA $0.25 \mathrm{~g} ;(-\bullet-)$, NEFA $0.50 \mathrm{~g}$.

performance responses to addition of fish oil in the diet of ruminants may be partly due to species differences.

In cows, increasing the amount of starch in PUFA-rich diets, in particular with PUFA from plant oils, modified the profile of $\mathrm{C} 18: 1$ and $\mathrm{C} 18: 2$ intermediates formed in the rumen $^{(29,30)}$ in favour of the trans-10 pathway, which is a factor associated with milk fat depression ${ }^{(3)}$. Such effects of milk fat depression and trans-10 pathway increase were not observed in the present study on adding fish oil and increasing the level of dietary starch (SFO treatment), in line with previous studies in goats receiving starchy diets and PUFA from plant oils ${ }^{(11,16)}$. The concentration of milk trans-10-18:1 with SFO was low compared with values observed in cows under similar dietary conditions $(0.7$ in the present study $v .3 .6 \%$ of total fatty acids with a diet with $3 \%$ DM intake added fat as $1 \%$ of fish oil and $2 \%$ of sunflower-seed oil $\left.{ }^{(31)}\right)$, confirming the lower occurrence, in goats compared with cows, of the shift of ruminal biohydrogenation towards the trans-10 pathway ${ }^{(16)}$. Altogether, these results show the absence of response of the ruminal biohydrogenation pathway to diets rich in starch and PUFA in the goat compared with the cow. On the other hand, an estimation of the degree of ruminal trans-18:1 reduction from the ratio of trans-18:1/(18:0+ cis-18:1+ trans-18:1) ${ }^{(31)}$ in milk (i.e. 0.20 and 0.33 , respectively, for SO and SFO) is in line with fish oil acting as an inhibitor of the conversion of trans-18:1 to stearic acid in the rumen ${ }^{(28)}$. In cows these milk ratios were higher for similar dietary conditions (values of 0.33 and 0.50 , respectively, with a diet with $3 \% \mathrm{DM}$ intake added fat as sunflower-seed oil or as $1 \%$ of fish oil and $2 \%$ of sunflower-seed oil ${ }^{(31)}$ ), suggesting that the ruminal biohydrogenation processes are more strongly altered in cows than in goats by PUFA addition to the diet.

The goats fed fish oil and sunflower-seed oil plus additional starch had higher percentages of milk 10:0+12:0+14:0 $(+21.4 \%)$, which are synthesised de novo, and lower percentages of the sum of $\mathrm{C} 18(-21.1 \%)$ than those fed sunflower-seed oil. This is in line with data on cows comparing diets similar to ours (for example, addition of fish oil to sunflower-seed oil $v$. sunflower-seed oil alone leading, respectively, to $+11.6 \%$ of milk $\mathrm{C} 10$ to $\mathrm{C} 14$ and $-11.9 \%$ of $\mathrm{C} 18^{(31)}$ ). Taken together, these results suggest that the sunflower-seed oil fatty acids or their metabolites inhibit the de novo fatty acid synthesis in the mammary gland more strongly than fatty acids of fish oil or their metabolites, and/ or that fish oil fatty acid modifies the metabolites of sunflower-seed oil fatty acids to less inhibitory products.

Even though milk concentrations of long-chain fatty acids $20: 5 n-3$ and $22: 6 n-3$ increased with SFO treatment, their concentrations remained low, with an apparent transfer rate from diet to milk fat of 4.1 and $3.6 \%$, respectively, in accordance with studies in cows ${ }^{(28,31)}$ and goats ${ }^{(14)}$. These results are due to the extensive biohydrogenation of PUFA in the rumen as well as the partitioning of these fatty acids into plasma cholesteroyl esters and phospholipid fractions which are not large providers of fatty acids to the mammary gland ${ }^{(32)}$.

\section{9-Desaturation}

We measured in vivo the $\Delta 9$-desaturation of VA to RA using a chemical tracer strategy and then related this measurement to other variables characterising the mammary $\Delta 9$-desaturase system assuming that the mammary gland in goats, like in cows $^{(8)}$, is the major site of fatty acid $\Delta 9$-desaturation. This assumption is supported by the absence of $\Delta 9$-desaturation of $\left[{ }^{14} \mathrm{C}\right]$ VA to $\left[{ }^{14} \mathrm{C}\right] \mathrm{RA}$ observed in bovine liver slices $^{(33)}$ and by the probable low lipomobilisation (as suggested by
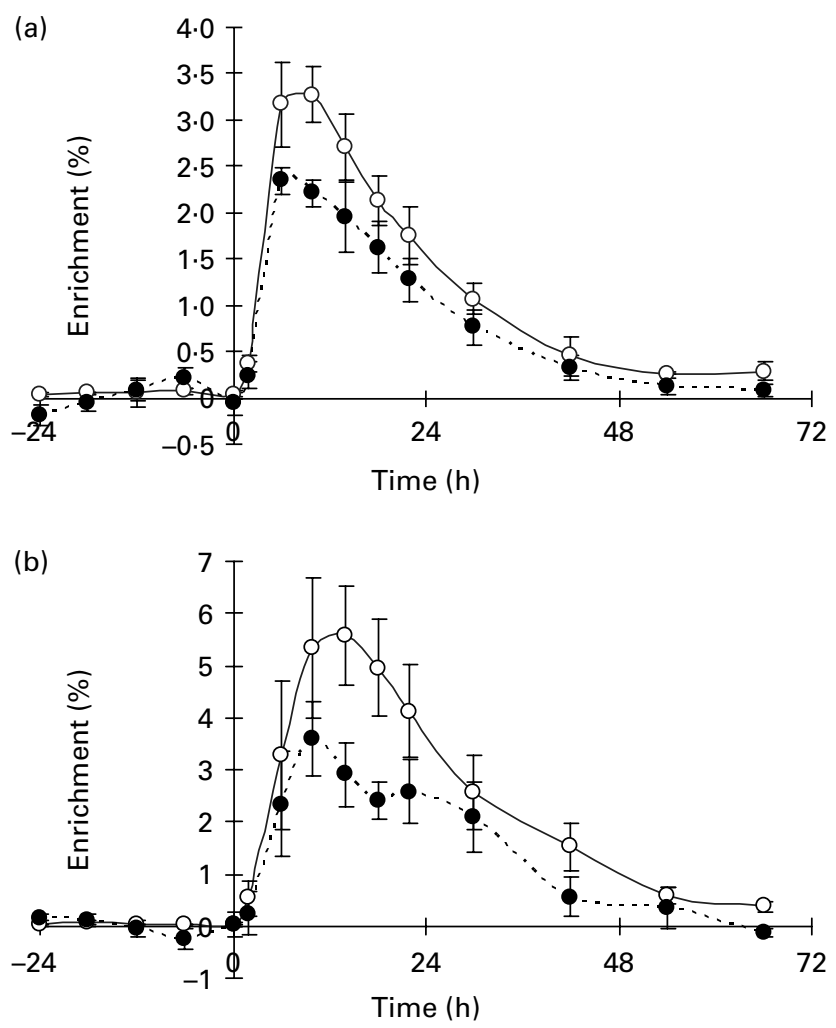

Fig. 2. Enrichment of ${ }^{13} \mathrm{C}$ in trans-11-18:1 (vaccenic acid; VA; -O-) and cis-9, trans-11-18:2 (rumenic acid; - - -) in milk fat of lactating goats injected intravenously with $\left[1-{ }^{13} \mathrm{C}\right] \mathrm{VA}$ at time zero, on (a) sunflower-seed oil and (b) sunflower-seed and fish oil plus starch treatments. The post-injection data are plotted at the mean time point for each collection period. Values are means for four goats, with standard errors represented by vertical bars. 
Table 4. Effect of dietary sunflower-seed oil alone or in combination with fish oil plus starch on the different steps of the metabolism of vaccenic acid (VA) and of cis-9, trans-11-conjugated linoleic acid (rumenic acid; RA) in goats

(Mean values with their standard errors for four goats per treatment)

\begin{tabular}{|c|c|c|c|c|c|c|}
\hline \multirow{2}{*}{$\begin{array}{l}\text { Treatment... } \\
\text { Variable calculated }\end{array}$} & \multicolumn{2}{|c|}{ so } & \multicolumn{2}{|c|}{ SFO } & \multirow[b]{2}{*}{$P$} & \multirow[b]{2}{*}{ Calculation* } \\
\hline & Mean & SEM & Mean & SEM & & \\
\hline VA converted to milk RA (\%) & $31 \cdot 7$ & 3.35 & $31 \cdot 6$ & $2 \cdot 82$ & 0.89 & 1 \\
\hline VA secreted in milk $24 \mathrm{~h}$ p.i. (g) & $3 \cdot 1$ & 0.52 & 2.9 & 0.95 & 0.49 & 2 \\
\hline Mammary uptake of VA $24 \mathrm{~h}$ p.i. (g) & 4.4 & 0.57 & $4 \cdot 1$ & 1.23 & 0.47 & 3 \\
\hline VA converted to milk RA $24 \mathrm{~h}$ p.i. (g) & 1.4 & 0.11 & 1.2 & 0.28 & 0.99 & 4 \\
\hline Secreted RA in milk $24 \mathrm{~h}$ p.i. (g) & 1.9 & 0.28 & 1.9 & 0.35 & 0.99 & 5 \\
\hline Milk RA from VA p.i. (\%) & $73 \cdot 1$ & 7.82 & 62.9 & 3.45 & 0.47 & 6 \\
\hline
\end{tabular}

SO, sunflower-seed oil; SFO, sunflower-seed oil and fish oil (2:1) plus starch from rolled barley; p.i., post-injection.

${ }^{*}$ Equations 1 to 6 are shown in the Materials and methods section.

the very low plasma NEFA concentration, 0.14 to $0.21 \mathrm{~mm}$; results not shown) in late-lactating goats in positive energy balance (Table 2) in the present study.

In our preliminary study we observed higher milk fat enrichment values for VA when injected intravenously as NEFA compared with TAG (Fig. 1). In the nutritional study we thus used ${ }^{13} \mathrm{C}$-labelled VA as $\mathrm{NEFA}$ and at a greater dose than in the preliminary study to ensure a sufficient enrichment of milk VA and RA because increased VA and RA secretions were expected due to lipid addition to the $\operatorname{diet}^{(11)}$, to estimate in vivo conversion of VA to RA. The enrichment was longer in the nutritional study (Fig. 2) than in the preliminary study (Fig. 1), which may be explained by the addition of lipid to the diets in the nutritional study.

All the studies examining the contribution of endogenous RA synthesis have been conducted in lactating cows and involved either a chemical inhibition of the $\Delta 9$-desaturase enzyme by sterculic acid ${ }^{(5,34,35)}$, or a quantification of the duodenal or abomasal flow of VA and RA to estimate the endogenous synthesis of $\mathrm{RA}^{(6,7,13,21,36,37)}$, or a tracer methodology to allow direct measurement of the conversion of VA to RA in vivo ${ }^{(8)}$. These studies have provided clear evidence that endogenous desaturation of VA is the main source of milk fat RA in cows (with 64-97\% RA coming from VA), but few of them provided an estimation of VA desaturation in the mammary gland: $25 \cdot 7^{(8)}, 28 \cdot 9^{(6)}, 19 \cdot 8^{(13)}$ and $21 \%{ }^{(7)}$. In the present study, direct measurements of ${ }^{13} \mathrm{C}$ enrichment of milk lipids following an intravenous injection of $1.5 \mathrm{~g}\left[{ }^{13} \mathrm{C}\right] \mathrm{VA}$ established that 31.7 and $31.6 \%$ of VA was desaturated in vivo in goats with $\mathrm{SO}$ and $\mathrm{SFO}$ treatments, respectively. The close agreement of estimates (20-32\%) of percentages of VA converted to RA across all these studies suggests that the percentage of VA converted to RA is more closely linked to the $\Delta 9$-desaturase enzyme than to other factors that differed between these studies: methodologies, ruminant species, dietary conditions (forage:concentrate ratio, lipid supplement) and circulating fluxes of VA.

Among the milk $\Delta 9$-desaturation ratios used to estimate the in vivo mammary $\Delta 9$-desaturation ${ }^{(3)}$, the variation of cis-9-14:1/14:0 was reported to be most closely correlated to the response of mammary $\Delta 9$-desaturase activity ${ }^{(38)}$, probably due to the low level of myristic and myristoleic acids in ruminant feedstuffs. In the present experiment, the four pair normalised ratios for $\Delta 9$-desaturation did not differ between treatments. The milk RA/(VA + RA) values of 39.4 and $41.5 \%$ for SO and SFO, respectively (Table 5), are numerically higher than the 31.7 and $31.6 \%$ of VA conversion to RA for SO and SFO, respectively (Table 4) which represents in vivo $\Delta 9$-desaturation measurement. The absence of a dietary treatment effect on VA $\Delta 9$-desaturation estimates is also in line with the $\Delta 9$-desaturase gene expression estimated by the mRNA abundance of SCD1 and SCD5, which was similar among treatments. The SCD5 gene was recently characterised in bovines ${ }^{(17)}$, and no data have been published

Table 5. Effect of dietary sunflower-seed oil alone or in combination with fish oil plus starch on mRNA relative abundance encoding for stearoyl-CoA desaturase 1 and 5 (SCD1 and SCD5) in mammary tissue and on the milk fatty acid $\Delta-9$ desaturation ratios in goats

(Mean values with their standard errors for four goats per treatment)

\begin{tabular}{|c|c|c|c|c|c|}
\hline \multirow[t]{2}{*}{ Treatment... } & \multicolumn{2}{|c|}{ SO } & \multicolumn{2}{|c|}{ SFO } & \multirow[b]{2}{*}{$P$} \\
\hline & Mean & SEM & Mean & SEM & \\
\hline \multicolumn{6}{|l|}{ mRNA relative abundance* } \\
\hline$S C D 1$ & 1.00 & 0.20 & 0.82 & 0.15 & 0.31 \\
\hline SCD5 & 1.00 & 0.29 & 0.74 & 0.19 & 0.66 \\
\hline \multicolumn{6}{|l|}{$\Delta-9$ Desaturation ratios } \\
\hline cis-9-14:1/(14:0+cis-9-14:1) & 0.023 & 0.003 & 0.025 & 0.012 & 0.85 \\
\hline cis-9-16:1/(16:0+cis-9-16:1) & 0.030 & 0.003 & 0.040 & 0.020 & 0.12 \\
\hline cis-9-18:1/(18:0 + cis-9-18:1) & 0.691 & 0.022 & 0.745 & 0.373 & 0.20 \\
\hline cis- 9, trans-11-18:2/(trans-11-18: $1+$ cis- 9, trans-11-18:2) & 0.394 & 0.012 & 0.415 & $0 \cdot 208$ & 0.66 \\
\hline
\end{tabular}

SO, sunflower-seed oil; SFO, sunflower-seed oil and fish oil (2:1) plus starch from rolled barley.

* $\mathrm{mRNA}$ levels expressed as fold change relative to SO treatment after normalisation with cyclophilin A mRNA. 
on its expression and nutritional regulation in ruminant mammary tissue. The present study shows that its expression may contribute to some extent to the mammary $\Delta 9$-desaturase activity.

Taken together, these results demonstrate that in our experimental conditions, the different variables used for studying the in vivo regulation of mammary $\Delta 9$-desaturase enzyme - gene expression (SCD1 and SCD5 mRNA), milk fatty acid $\Delta 9$-desaturation ratios, and direct measurement of the in vivo $\Delta 9$-desaturation by a chemical tracer technique are consistent and show the absence of variation of the $\Delta 9$-desaturation between treatments.

Our initial hypothesis was that SFO treatment would negatively affect the mammary $\Delta 9$-desaturase system due to the negative effect of the very-long-chain PUFA (n-3) of fish oil ${ }^{(18)}$ and/or of specific intermediates that are synthesised via the trans-10 pathway in the rumen ${ }^{(3)}$ due to interaction between PUFA and additional starch.

In cows fed protected fish oil ${ }^{(18)}$, a down-regulation of SCD1 gene expression was reported, as in goats fed formaldehyde-treated linseed ${ }^{(24)}$. The relatively low incorporation and secretion of long-chain PUFA (20:5n-3 and 22:6n-3) in milk in the SFO treatment (Table 3) could explain the lack of changes in goats' SCD1 mRNA abundance in the present experiment compared with those obtained in cows fed protected fish oil ${ }^{(18)}(20: 5 n-3$ and $22: 6 n-3$ were $0 \cdot 13$ and $0.09 \%$ of total fatty acids, respectively, for SFO treatment in goats $v .0 .21$ and $0.13 \%$, respectively, in cows ${ }^{(18)}$ ).

In addition, it was reported in dairy cows fed diets rich in starchy concentrate with addition of a mixture of soyabean oil and fish oil (2:1) that specific intermediates formed during the biohydrogenation of PUFA in the rumen could be involved in the down-regulation of lipogenic gene expression (in particular of $S C D 1$ ) and milk fat depression ${ }^{(39)}$. One of these inhibitory intermediates was the trans-10, cis-12-conjugated linoleic acid, which also reduced milk fat $\Delta 9$-desaturase ratios in cows ${ }^{(40,41)}$ and in goats ${ }^{(42-44)}$. In the present study, the absence of increase in the milk trans-10-18:1 concentration with SFO treatment is in line with other studies in goats ${ }^{(11,16)}$. The low concentration of this fatty acid in milk (Table 3) is an indicator of the low occurrence of the ruminal trans-10 pathway, which probably explains the absence of effect of our dietary treatments on the different variables used to estimate the in vivo regulation of mammary $\Delta 9$-desaturation.

The percentages of milk RA coming from VA desaturation were estimated to be 73 and $63 \%$ for the SO and SFO treatments, respectively, in line with the 86 and $68 \%$ found by measuring duodenal and milk flows in cows fed $2 \%$ of DM intake of soyabean oil or fish oil, respectively ${ }^{(13)}$. Thus, 27 and $37 \%$ of the RA secreted in milk for SO and SFO, respectively, are taken up directly by the mammary gland.

\section{Conclusions}

Using ${ }^{13} \mathrm{C}$-labelled VA, we have shown that in goats, $32 \%$ of VA was $\Delta$ 9-desaturated into RA and that milk RA originating from VA represents $63-73 \%$ of total milk RA. In addition, feeding sunflower-seed oil in combination with fish oil plus additional starch, compared with sunflower-seed oil alone, had no effect either on the percentages of VA $\Delta 9$-desaturated into RA and milk RA originating from VA or on the other variables used to estimate the $\triangle 9$-desaturase system (SCD1 and SCD5 gene expression; milk $\Delta$ 9-desaturase ratios). We hypothesise that our dietary treatments were not extreme enough to induce a response of the $\Delta 9$-desaturase system in goats, which is probably due to caprine specificities that include (i) a lower occurrence of the shift of ruminal biohydrogenation towards the trans-10 pathway, thus limiting the synthesis of biohydrogenation product inhibitors of the $\Delta$ 9-desaturase, and (ii) a lower sensitivity of the mammary $\Delta$ 9-desaturase to long-chain PUFA, compared with cows. Further experiments with more sharply contrasting diets and with comparison of cows and goats fed the same diets would test these hypotheses.

\section{Acknowledgements}

The present study was supported by the ANR-Agence Nationale de la Recherche under the Programme National de Recherche en Alimentation et Nutrition Humaine (project ANR-05-PNRA-No.5.E.24).

The authors gratefully acknowledge the staff of the Animal Nutrition and Metabolism Unit Les Cèdres, in particular Denis Roux, Christophe Mathevon, André Combeau and Dominique Roux, for the diligent care of experimental animals, R. Jailler and his team for assisting in the slaughtering of experimental animals, the technical assistance of Jordann Domagalsky, Didier Bany, Bernard Lyan and Charlotte Joly, the advice of Pierre Juaneda and the supply of $\left[{ }^{13} \mathrm{C}\right] \mathrm{VA}$ by Olivier Loreau (Commissariat à l'Énergie Atomique (Commission for Atomic Energy; CEA), Saclay and Cadarache, France).

All authors contributed to the preparation of the paper and agreed with the submitted manuscript content. L. B. and Y. C. designed the research and J.-M. C. was the coordinator of the Transqual project. L. B., J. M. and J. R. performed the research and J. M., L. B., P. C. and E. P.-G. analysed the samples. L. B., Y. C., F. G. and J. M. analysed the data and drafted the paper.

There are no conflicts of interest.

\section{References}

1. Lawson RE, Moss AR \& Givens DI (2001) The role of dairy products in supplying conjugated linoleic acid to man's diet: a review. Nutr Res Rev 14, 153-172.

2. Wahle KW, Heys SD \& Rotondo D (2004) Conjugated linoleic acids: are they beneficial or detrimental to health? Prog Lipid Res 43, 553-587.

3. Bauman DE \& Griinari JM (2003) Nutritional regulation of milk fat synthesis. Апnи Rev Nutr 23, 203-227.

4. Parodi PW (2005) Dairy product consumption and the risk of breast cancer. $J$ Am Coll Nutr 24, 556S-568S.

5. Griinari JM, Corl BA, Lacy SH, et al. (2000) Conjugated linoleic acid is synthesized endogenously in lactating dairy cows by $\Delta$ (9)-desaturase. J Nutr 130, 2285-2291.

6. Shingfield KJ, Ahvenjarvi S, Toivonen V, et al. (2007) Transfer of absorbed cis-9, trans-11 conjugated linoleic acid into milk is biologically more efficient than endogenous synthesis from absorbed vaccenic acid in lactating cows. J Nutr 137, 1154-1160.

7. Glasser F, Ferlay A, Doreau M, et al. (2008) Long-chain fatty acid metabolism in dairy cows: a meta-analysis of milk fatty acid yield in relation to duodenal flows and de novo synthesis. J Dairy Sci 91, 2771-2785. 
8. Mosley EE, Shafii B, Moate PJ, et al. (2006) Cis-9, trans-11 conjugated linoleic acid is synthesized directly from vaccenic acid in lactating dairy cattle. J Nutr 136, 570-575.

9. Chilliard Y, Ferlay A, Rouel J, et al. (2003) A review of nutritional and physiological factors affecting goat milk lipid synthesis and lipolysis. J Dairy Sci 86, 1751-1770.

10. Jensen RG (2002) The composition of bovine milk lipids: January 1995 to December 2000. J Dairy Sci 85, 295-350.

11. Chilliard Y, Glasser F, Ferlay A, et al. (2007) Diet, rumen biohydrogenation, cow and goat milk fat nutritional quality. Eur J Lipid Sci Technol 109, 828-855.

12. AbuGhazaleh AA, Schingoethe DJ, Hippen AR, et al. (2003) Milk conjugated linoleic acid response to fish oil supplementation of diets differing in fatty acid profiles. J Dairy Sci $\mathbf{8 6}$, 944-953.

13. Qiu X, Eastridge ML \& Firkins JL (2004) Effects of dry matter intake, addition of buffer, and source of fat on duodenal flow and concentration of conjugated linoleic acid and trans-11 C18:1 in milk. J Dairy Sci 87, 4278-4286.

14. Gagliostro G, Rodriguez A, Pellegrini A, et al. (2006) Effects of fish oil or sunflower plus fish oil supplementation on conjugated linoleic acid (CLA) and omega 3 fatty acids in goat milk. Rev Argent Prod Anim 26, 71-87.

15. Shingfield KJ \& Griinari JM (2007) Role of biohydrogenation intermediates in milk fat depression. Eur J Lipid Sci Technol 109, 799-816.

16. Bernard L, Shingfield KJ, Rouel J, et al. (2009) Effect of plant oils in the diet on performance and milk fatty acid composition in goats fed diets based on grass hay or maize silage. $\mathrm{Br} \mathrm{J} \mathrm{Nutr}$ 101, 213-224

17. Lengi AJ \& Corl BA (2007) Identification and characterization of a novel bovine stearoyl-CoA desaturase isoform with homology to human SCD5. Lipids 42, 499-508.

18. Ahnadi CE, Beswick N, Delbecchi L, et al. (2002) Addition of fish oil to diets for dairy cows. II. Effects on milk fat and gene expression of mammary lipogenic enzymes. J Dairy Res $\mathbf{6 9}$, $521-531$

19. Viswanadha S, Giesy JG, Hanson TW, et al. (2003) Dose response of milk fat to intravenous administration of the trans-10, cis-12 isomer of conjugated linoleic acid. J Dairy Sci 86, 3229-3236.

20. Association of Official Analytical Chemists (1997) Official Methods of Analysis, 16th ed. Gaithersburg, MD: AOAC International.

21. Loor JJ, Ferlay A, Ollier A, et al. (2005) Relationship among trans and conjugated fatty acids and bovine milk fat yield due to dietary concentrate and linseed oil. J Dairy Sci 88, 726-740.

22. Mosley EE, Powell GL, Riley MB, et al. (2002) Microbial biohydrogenation of oleic acid to trans isomers in vitro. J Lipid Res 43, 290-296.

23. Christie WW (2003) Lipid analysis. In Isolation, Separation, Identification and Structural Analysis of Lipids. Bridgewater, UK: The Oily Press, PJ Barnes, Associates.

24. Bernard L, Rouel J, Leroux C, et al. (2005) Mammary lipid metabolism and milk fatty acid secretion in alpine goats fed vegetable lipids. J Dairy Sci 88, 1478-1489.

25. Yamamoto K, Shibahara A, Nakayama T, et al. (1991) Determination of double-bond positions in methylene-interrupted dienoic fatty acids by GC-MS as their dimethyl disulfide adducts. Chem Phys Lipids 60, 39-50.

26. Wolfe RR (editor) (1992) Determination of isotopic enrichment by gas chromatography-mass spectrometry. In Radioactive and Stable Isotope Tracers in Biomedicine. Principles and Practice of Kinetic Analysis, pp. 49-85. New York: Wiley-Liss.

27. Jarrige R (editor) (1989) Recommended Allowance and Feed Table. Paris: INRA.
28. Chilliard Y, Ferlay A \& Doreau M (2001) Effect of different types of forages, animal fat or marine oils in cow's diet on milk fat secretion and composition, especially conjugated linoleic acid (CLA) and polyunsaturated fatty acids. Livest Prod Sci 70, 31-48.

29. Griinari JM, Dwyer DA, McGuire MA, et al. (1998) Transoctadecenoic acids and milk fat depression in lactating dairy cows. J Dairy Sci 81, 1251-1261.

30. Piperova LS, Teter BB, Bruckental I, et al. (2000) Mammary lipogenic enzyme activity, trans fatty acids and conjugated linoleic acids are altered in lactating dairy cows fed a milk fat-depressing diet. J Nutr 130, 2568-2574.

31. Palmquist DL \& Griinari JM (2006) Milk fatty acid composition in response to reciprocal combinations of sunflower and fish oils in the diet. Anim Feed Sci Technol 131, 358-369.

32. Offer NW, Speake BK, Dixon J, et al. (2001) Effect of fish-oil supplementation on levels of ( $n$-3) poly-unsaturated fatty acids in the lipoprotein fractions of bovine plasma. Anim Sci 73, 523-531.

33. Gruffat D, De La Torre A, Chardigny JM, et al. (2005) Vaccenic acid metabolism in the liver of rat and bovine. Lipids 40, 295-301.

34. Corl BA, Baumgard LH, Dwyer DA, et al. (2001) The role of $\Delta(9)$-desaturase in the production of cis-9, trans-11 CLA. J Nutr Biochem 12, 622-630.

35. Kay JK, Mackle TR, Auldist MJ, et al. (2004) Endogenous synthesis of cis-9, trans-11 conjugated linoleic acid in dairy cows fed fresh pasture. J Dairy Sci 87, 369-378.

36. Piperova LS, Sampugna J, Teter BB, et al. (2002) Duodenal and milk trans octadecenoic acid and conjugated linoleic acid (CLA) isomers indicate that postabsorptive synthesis is the predominant source of cis-9-containing CLA in lactating dairy cows. J Nutr 132, 1235-1241.

37. Loor JJ, Ferlay A, Ollier A, et al. (2005) High-concentrate diets and polyunsaturated oils alter trans and conjugated isomers in bovine rumen, blood, and milk. J Dairy Sci 88, 3986-3999.

38. Bernard L, Leroux C \& Chilliard Y (2008) Expression and nutritional regulation of lipogenic genes in the ruminant lactating mammary gland. Adv Exp Med Biol 606, 67-108.

39. Harvatine KJ \& Bauman DE (2006) SREBP1 and thyroid hormone responsive spot 14 (S14) are involved in the regulation of bovine mammary lipid synthesis during diet-induced milk fat depression and treatment with CLA. J Nutr 136, $2468-2474$

40. Baumgard LH, Corl BA, Dwyer DA, et al. (2000) Identification of the conjugated linoleic acid isomer that inhibits milk fat synthesis. Am J Physiol Regul Integr Comp Physiol 278, R179-R184.

41. Peterson DG, Matitashvili EA \& Bauman DE (2003) Dietinduced milk fat depression in dairy cows results in increased trans-10, cis-12 CLA in milk fat and coordinate suppression of mRNA abundance for mammary enzymes involved in milk fat synthesis. J Nutr 133, 3098-3102.

42. Andrade PVD \& Schmidely P (2006) Effect of duodenal infusion of trans 10 , cis12-CLA on milk performance and milk fatty acid profile in dairy goats fed high or low concentrate diet in combination with rolled canola seed. Reprod Nutr Dev 46, $31-48$.

43. Lock AL, Rovai M, Gipson TA, et al. (2008) A conjugated linoleic acid supplement containing trans-10, cis-12 conjugated linoleic acid reduces milk fat synthesis in lactating goats. J Dairy Sci 91, 3291-3299.

44. Shingfield KJ, Rouel J \& Chilliard Y (2009) Effect of calcium salts of a mixture of conjugated linoleic acids containing trans-10, cis-12 in the diet on milk fat synthesis in goats. $\mathrm{Br} \mathrm{J}$ Nutr 101, 1006-1019. 